\title{
Guest Editors' Introduction: The frontiers of strategic management research
}

\section{Kamel Mellahi and Harry Sminia}

This is an exciting time for scholarly research in the area of strategic management. After decades of lack of self-confidence about its intellectual heritage and influence, the field of strategic management has grown by leaps and bounds in the past two decades to establish itself as a distinct and well-accepted field of scholarly research in the field of management (Hoskisson et al. 1999; Mahoney and McGahan 2007). In light of the current growing pace and breadth in strategic management research, we believe this is an appropriate time to take stock of the considerable volume of research generated in the last two decades, draw some lessons and set an agenda for future research. Towards this end, this special issue brings together a team of leading experts to undertake a comprehensive in-depth review of five active research fronts in strategic management and to provide pointers for future research endeavours.

The goal of this editorial paper is not to provide a comprehensive review of research in the area, as several recent papers have summarized current and past trends in strategic management research (Herrmann 2005;
Hoskisson et al. 1999; Mahoney and McGahan 2007). The aim of this editorial is threefold: to provide a brief background for the leading debates that dominate the strategic management research agenda; to raise some fundamental questions about the current and future state of strategic management research; and to highlight the key points raised by the five papers published in this special issue.

\section{Content-Structure Divide and Leading Debates}

With the development of the field, strategic management research has become divided into two separate branches: content research seeking to answer the question of what underpins firms' competitive advantage, and process research approaching strategic management from the standpoint of how firms' strategies emerge over time. To put it another way, content research is concerned with the strategy part of strategic management, while process research is more concerned with the management part. Indeed, most of the strategy 


\section{Guest Editors' Introduction}

research carried out to date can be placed fairly easily into one of the two branches. Although we share the view that the deeply rooted divide between content and process research is counter-productive and acts as a barrier to greater understanding of strategic management activities (see Huff and Reger 1987; Pettigrew 1992; Ketchen et al. 1996), we structured this special issue along the content-process divide to reflect the current state of strategic management research. We allocated three papers to strategy content research and two to process research. Interestingly, a shared theme between the five papers in this special issue is the notion that, to take the field of strategic management forward, the two strands have to acknowledge and build on each other. However, the jury is still out on the viability and feasibility of a rapprochement between content and process researchers. Indeed, a number of scholars believe that there is no way of bridging the two realms by reference to a shared conceptual framework. This is because content and process researchers draw on distinct theoretical branches and use different languages, different concepts and different sets of tools and techniques.

\section{Strategy Content}

Although the early roots of the content branch of strategic management can be traced back to the 1910s and, in particular, to a business policy module at Harvard Business School (see Ghemawat 2002), the field emerged as a scholarly research discipline in the 1960s in the work of pioneering scholars such as Ansoff (1965), Chandler (1962) and Andrews (1971). The 1960s is characterized by predominantly applied case-study research which produced several descriptive and prescriptive tools such as SWOT and PEST analysis. While still widely used in teaching and consultancy, these tools have often been accused of having shallow theoretical foundations. This type of research dominated strategic management research well into the 1970 s.
It was not until the mid to late 1970s that sound strategic management research began to emerge. Pioneer strategy scholars such as Michael Porter began to draw on insights from economics and, in particular, the structureconduct-performance paradigm of industrial organization (Bain 1959) to explain firms' performance and growth. Porter provided a remarkable set of new insights about industry structure and strategic groups and, perhaps most important of all, about the competitive factors that determine firm performance. Building on Porter's work, a considerable amount of theoretical and empirical work was carried out to explain the link between industry structure, competitive positioning in an industry and performance. The core argument of the Porterian school is that industry characteristics determine firm performance. Competitive advantage, according to Porter (1980, 1985), depends on firms' ability to position and differentiate themselves in their industry.

Meanwhile, as early as the 1980s, scholars in strategic management expressed concerns about the exaggerated impact of the industry on firms' performance and growth. These concerns brought an increasing urgency to the debate on the merits of industry-level analysis. In particular, strategic management scholars started asking new questions: Why are firms different? Why do firms outperform others? And why do their performance differences persist over time? (Barney 1991; Prahalad and Hamel 1990; Wernerfelt 1984). These scholars called into question the impact of industry structure on firm performance and growth and offered a rebuttal to the argument that the industry matters more than the firm. This, then emerging, body of research turned the Porterian school on its head: it provided evidence to suggest that firm-level resources and capabilities, not industry characteristics, are the primary determinants of firms' performance (Barney 1991; Prahalad and Hamel 1990; Wernerfelt 1984). As a result, the 1990s witnessed a shift in interest in strategic management research from external and industry-level factors to internal factors. This new research 
agenda led to the birth of the resource-based view (RBV) (Barney 1991; Wernerfelt 1984) and what can be considered as its offshoot, dynamic capabilities (DCs) (Teece et al. 1997).

The RBV and DCs emerged as dominant lines of inquiry and received overwhelming success in strategic management research and adjacent disciplines. Thanks to the RBV and DCs, the old accusation of strategic management research of 'promiscuous borrowing of other disciplines and sub-fields of management' (Pettigrew et al. 2002, 6) is no longer valid. Current research in strategic management does not only draw on other fields, but contributes to them as well. However, although the RBV and DCs approaches have made significant advances to our knowledge during the last two decades, a review of current research points to a ceiling effect, as current contributions are becoming dull, wrestling with hair-splitting issues and making only minuscule advances to the current stock of knowledge. Further, there are still areas that warrant further investigation; as Hoskisson et al. $(1999,445)$ put it: 'despite overwhelming agreement on the types of critical resources and capabilities, there are several remaining areas of uncertainty in this field'. Reflecting the dominance of the RBV and DCs approaches in current strategy content research, we invited two papers; one on RBV (Lockett et al. 2009) and one on DCs (Ambrosini and Bowman 2009). We asked the authors to look for the remaining nuggets of gold as well as the blind spots in the two approaches, to re-energize the strategy research agenda.

A major new thrust of strategic management research is the area of global strategy. This is a reflection of the globalization of the world economy and the dramatic increase in international business activities. Globalization brings with it new issues and challenges that strategic management scholars have to wrestle with. Several aspects of our dominant research paradigm and research methods may need to be reconsidered if the complexities of international strategic management activities are to be captured fully. For instance, Peng et al. (2008) charged that current approaches in strategic management - the RBV and the industry-based view - are not adequate on their own to capture the complexity of strategic management at a global level, because they neglect the role of institutions in international business strategy. One of the most fundamental questions confronting international business strategy researchers is: "What determines the success and failure of firms around the world?' (Peng et al. 2008, 1). The quest to find an answer to this question has invigorated strategic management research and sparked a number of debates over the antecedents and outcomes of global strategic management. We invited Mike Peng and Erin PleggenkuhleMiles to discuss leading debates within global strategy research.

\section{Strategy Process}

The realization that rational decision-making within organizations is more of a theoretical idea than an empirical reality can be traced back to March and Simon (1958) and Cyert and March (1963). This insight entered the realm of strategic management with a range of case studies, starting with Bower (1970), Mintzberg et al. (1973), Quinn (1980) and Pettigrew (1985), with conclusions increasingly being drawn that the findings from the content realm in fact only had limited effect within actual strategy formation processes, if at all. A picture emerged that it was not so much a meticulous exercise of strategy formulation and implementation that determined how a firm established the way in which it wanted to compete, but that it was a process in which internal politics, organizational culture and/or management cognition had the upper hand. This process approach in strategic management has recently been joined by an approach that focuses on the people who practise strategic management on a day-to-day basis as part of their jobs (Whittington 1996; Jarzabkowski 2005). This study of the microprocesses of strategic management came to be 


\section{Guest Editors' Introduction}

known as the strategy-as-practice approach. The first of the two strategy process papers, by Jarzabkowski and Spee (2009), examines what strategy-as-practice has been contributing to this realm and what still needs to be investigated. The second paper, by Sminia (2009), examines where the original strategy process research agenda has led us and where it needs to go.

\section{The Papers in the Special Issue}

The paper by Lockett et al. (2009) reviews the RBV literature and goes beyond the standard critiques of the RBV framework that focus on matters of measurements difficulties and inconsistency of empirical findings to provide an elegant critical analysis of the RBV framework. They trace the RBV academic origins, provide a comprehensive discussion of its evolution, evaluate the empirical evidence to date, and provide practical insights from the RBV. They highlight seven specific methodological challenges that face RBV scholars in the design and analysis of RBV research. They conclude by outlining four suggestions on where RBV scholars should focus their research efforts in the future and the key questions that scholars should aim to address.

Ambrosini and Bowman (2009) discuss many of the specific conceptual and empirical challenges facing DCs researchers. Throughout, Ambrosini and Bowman (2009) adopt a cautious tone toward the current enthusiasm about DCs in strategic management research, and question some of the most established ideas in the DCs literature. After briefly tracing the evolution of scholarly thought on DCs, Ambrosini and Bowman provide a framework that links the value creation process of DCs with four possible outcomes: sustained competitive advantage, temporary competitive advantage, competitive parity or failure. They recommend that, in the face of the difficulties involved in identifying and measuring DCs, more detailed design work should be carried out. They argue that, given that DCs are developed over time, the way in which practi- tioners identify, develop, deploy and renew DCs needs to be the focus of current and future research. They posit that qualitative research methods may overcome some aspects of measurement and offer a unique insight into the details of how DCs are deployed in practice. In particular, they suggest that the strategy-as-practice approach, reviewed in this issue by Jarzabkowski and Spee (2009), is one of the most promising approaches that could shed some light on the practices that make up DCs. The paper finishes with a call for more, but different, research, because we still do not fully understand precisely how DCs are identified, deployed and renewed.

Peng and Pleggenkuhle-Miles's (2009) paper centres on two issues: What are the leading debates in global strategy research? And what is the most appropriate framework for studying the factors that determine performance globally? On the first issue, they identify four leading debates that proved to be a wedge issue in current global strategy research: cultural vs institutional distance, global vs regional geographic diversification, convergence vs divergence in corporate governance, and domestic vs overseas corporate social responsibility. In addition to a comprehensive review of the literature on both sides of the debates, Peng and Pleggenkuhle-Miles provide an excellent synthesis of the available literature and raise some important research questions to guide future research efforts. On the second issue, they provide compelling arguments for the suitability of the institution-based view as an overarching theoretical perspective for studying the factors that determine global performance. They show how the institutionbased view captures the dynamics of global strategy over time and helps us move forward the four debates discussed in the paper.

The strategy-as-practice approach, reviewed by Jarzabkowski and Spee (2009), with its quest to find out more about the actual practice of doing strategic management, is clearly focused on the management part of strategic management. Not surprisingly, most of the strategy-as-practice research has concentrated 
on what went on inside organizations and focused on what Jarzabkowski and Spee (2009) dub as micro- and meso-praxis, which is concerned with the individual or the suborganizational level, respectively. They argue that what has been done on macro-praxis in the outer context is almost exclusively theoretical. In addition, they make an explicit call to include 'outcomes' in some shape or form in future strategy-as-practice research. They appear to want to stay clear of turning performance into the ultimate dependent variable, because they find the connotation that this term has with financial parameters too limiting. Nevertheless, these are very clear indications that the effectiveness of strategy praxis has to become part and parcel of the strategy-as-practice research agenda.

The research contributions that have been collected under the process research label as reviewed by Sminia (2009) clearly fall under the management part of strategic management research as well. This endeavour is pretty much preoccupied with trying to understand how a strategy is actually realized within a firm. Although there is variety in the manner in which the process is characterized, the end result is mostly descriptive. There is acknowledgement of a management contribution to the course and the outcome of the process. However, Sminia (2009) observes that the question of to what extent the strategies that were realized helped the firm to be more successful was very rarely asked, as was the question of what managers can do to direct a firm in a more favourable direction, based on the knowledge that this research has produced. As a remedy, Sminia (2009) suggests extending the process approach to the realm that is traditionally occupied by strategy content research, namely the outer context, and apply the same basic sociological inspired reasoning that has been used to study strategy process to the question of how strategic positions are being realized in industries and on markets. Additionally, he introduces the notion of 'generative mechanism' both as a focal point for explaining the realization of a strategy as well as a point of action for management intervention in the process.

Although the five papers included in this special issue cover what we think are the current frontiers of strategic management research, we do not propose that these are the only leading debates in the field. Also, given the review nature of this special issue, we decided not to include emerging areas of research such as strategic entrepreneurship (Hitt et al. 2001), or what we believe are important issues that have so far been neglected, such as organizational failure (Mellahi and Wilkinson 2004; Sminia 2003; Wilkinson and Mellahi 2005). Future strategic management research needs to pay considerable attention to these emerging and or important but neglected issues.

The papers in this special issue provide a foundation for future research on the topics that are currently of high interest to strategic management researchers. Each paper presented herein sought to summarize, integrate and extend the existing literature in a unique and value-adding way to provide a foundation for important research agendas in strategic management. We hope that the recommendations presented in this special issue help to stimulate new thinking about the challenges facing strategic management researchers. Finally, we should like to stress that, despite the remarkable achievements in strategic management research and enormous advances in the sophistication of strategy research over the last few decades, judging by the papers in this special issue it is quite clear that we are still a long way from providing satisfactory answers to the questions we pose. We have much to learn.

\section{Acknowledgments}

We are indebted to a number of people who helped bring this project to fruition. We are deeply grateful to the editors of the International Journal of Management Reviews for providing us with the opportunity to edit this issue. We are indebted to the reviewers for their useful suggestions and critical remarks. 


\section{Guest Editors' Introduction}

Finally, we thank the authors for providing us with stimulating and insightful papers.

\section{References}

Ambrosini, V. and Bowman, C. (2009). What are dynamic capabilities and are they a useful construct in strategic management? International Journal of Management Reviews, this issue.

Andrews, K. (1971). The Concept of Corporate Strategy. Homewood, IL: Irwin.

Ansoff, H.I. (1965). Corporate Strategy: an Analytical Approach to Business Policy for Growth and Expansion. New York: McGraw-Hill.

Bain, J. (1959). Industrial Organization, New York: Wiley.

Barney, J. (1991). Firm resources and sustained competitive advantage. Journal of Management, 17, 99-120.

Bower, J.L. (1970). Managing the Resource Allocation Process. Cambridge, MA: Harvard University Press.

Chandler, A.D. (1962). Strategy and Structure: Chapters in the History of the American Industrial Enterprise. Cambridge, MA: MIT Press.

Cyert, R.L. and March, J.G. (1963). A Behavioral Theory of the Firm. Englewood Cliffs, NJ: Prentice Hall.

Ghemawat, P. (2002). Competition and business strategy in historical perspective. Business History Review, 76(1), 37-74.

Herrmann, P. (2005). Evolution of strategic management: the need for new dominant designs. International Journal of Management Reviews, 7, 111-130.

Hitt, M.A., Ireland, D.R., Camp, S.M., and Sexton, D.L. (2001). Guest editors' introduction to the special issue: strategic entrepreneurship: Entrepreneurial strategies for wealth creation. Strategic Management Journal, 22, 479-491.

Hoskisson, R.E., Hitt, M.A., Wan, W.P. and Yiu, D. (1999). Theory and research in strategic management: swings of pendulum. Journal of Management, 25, 417-456.

Huff, A.S. and Reger, R. (1987). A review of strategic process research. Journal of Management, 13, 21136.

Jarzabkowski, P. (2005). Strategy As Practice: An Activity-based Approach. London: Sage.

Jarzabkowski, P. and Spee, P.A. (2009). Strategyas-practice: a review and future directions for the field. International Journal of Management Reviews, this issue.
Ketchen, D.J. Jr, Thomas, J.B. and McDaniel, R.R. Jr (1996). Process, content, and context: synergistic effects on organizational performance. Journal of Management, 22, 231-257.

Lockett, A., Thompson, S. and Morgenstern, U. (2009). Reflections on the development of the RBV. International Journal of Management Reviews, this issue.

Mahoney, T.J. and McGahan, A.M. (2007). The field of strategic management within the evolving science of strategic organization. Strategic Organization, 5(1), 79-99.

March, J.G. and Simon, A.H. (1958). Organizations. New York: John Wiley.

Mellahi, K and Wilkinson, A. (2004). Organizational failure: a critique of recent research and a proposed integrative framework, International Journal of Management Reviews, 1, 21-41.

Mintzberg, H. (1973). The Nature of Managerial Work. New York: Harper \& Row.

Peng, M.W. and Pleggenkuhle-Miles, E.G. (2009). Current debates in global strategy. International Journal of Management Reviews, this issue.

Peng, M.W., Denis Y., Wang, L. and Yi, J. (2008). An institution-based view of international business strategy: a focus on emerging economies. Journal of International Business Studies, 39, 920-936.

Pettigrew, A. (1992). The character and significance of strategy process research. Strategic Management Journal, 13, 5-16.

Pettigrew, A.M. (1985). The Awakening Giant: Continuity and Change in ICI. Oxford: Basil Blackwell.

Pettigrew, A.M., Thomas, H. and Whittington, R. (2002). Strategic management: the strengths and limitations of a field. In Pettigrew, A.M., Thomas, H. and Whittington, R. (eds), Handbook of Strategy and Management. London: Sage, pp. 3-29.

Porter, M.E. (1980). Competitive Strategy: Techniques for Analyzing Industries and Competitors. New York: Free Press.

Porter, M.E. (1985). Competitive Advantage: Creating and Sustaining Superior Performance. New York: Free Press.

Prahalad, C.K. and Hamel, G. (1990). The core competence of the corporation. Harvard Business Review, 68(3), 79-91.

Quinn, J.B. (1980). Strategies for Change: Logical Incrementalism. Homewood, IL: Richard D. Irwin.

Sminia, H. (2003). The failure of the Sport7 TV-channel: controversies in a business network. Journal of Management Studies, 40, 1621-1649.

Sminia, H. (2009). Process research in strategy formation: theory, methodology, and relevance. 
International Journal of Management Reviews, this issue.

Teece, D.J., Pisano, G. and Shuen, A. (1997). Dynamic capabilities and strategic management. Strategic Management Journal, 18, 509-533

Wernerfelt, B. (1984). A resource-based view of the firm. Strategic Management Journal, 5, 171-180.

Whittington, R. (1996). Strategy as practice. Long Range Planning, 29, 731-735.
Wilkinson, A. and Mellahi, K. (2005). Organizational failure introduction to the special issue. Long Range Planning, 38, 233-238.

Kamel Mellahi and Harry Sminia are from The University of Sheffield, 9 Mappin Street, Sheffield S1 4DT, UK. 